\title{
SOSIALISASI PROSES REKRUTMEN, SELEKSI, PELATIHAN, SERTA PERLINDUNGAN HUKUM BAGI CALON TENAGA KERJA INDONESIA (TKI) LEGAL DI JAWA BARAT
}

\author{
Dina Sartika \\ dina.sartika@ unpad.ac.id \\ Sri Djatnika \\ sri.djatnika@unpad.ac.id \\ Mery Citra Sondari \\ mery.sondari@unpad.ac.id
}

\section{UNIVERSITAS PADJADJARAN}

\begin{abstract}
ABSTRAK
Badan Nasional Penempatan dan Perlindungan Tenaga Kerja Indonesia (BNP2TKI) melaporkan bahwa jumlah masyarakat Jawa Barat (Jabar) yang bekerja sebagai Tenaga Kerja Indonesia (TKI) di luar negeri merupakan yang tertinggi dibanding daerah lain yaitu sebanyak 50.910 orang pada tahun 2018. Sayangnya, problematika TKI muncul sejak awal sebelum proses keberangkatan dari Indonesia. Mulai dari pendaftaran TKI melalui agen illegal, atau oknum makelar yang datang ke desa dengan meminta pembayaran sejumlah uang kemudian menjanjikan penempatan di negara tertentu. Mayoritas dari mereka berpendidikan rendah. Akhirnya, mereka berangkat dengan cara illegal, digaji rendah, bahkan tidak sepenuhnya gaji dapat mereka terima karena dipotong oleh oknum makelar tersebut. Yang paling fatal, akses mereka terhadap dunia luar tertutup dan rentan pelecehan serta kekerasan. Untuk itu, edukasi terhadap calon TKI mengenai proses rekrutmen, seleksi, pelatihan, serta perlindungan hukum bagi calon TKI legal sebaiknya dilakukan untuk mengurangi permasalahan social yang mungkin terjadi di kemudian hari. Dengan demikian, jumlah Tenaga Kerja Indonesia illegal serta risiko permasalahan TKI di luar negeri dapat dikurangi.
\end{abstract}

Kata kunci: Legal, Perlindungan Hukum, Rekrutmen dan Seleksi, Tenaga Kerja Indonesia.

\section{PENDAHULUAN}

Indonesia merupakan negara dengan jumlah populasi terbesar keempat di dunia dengan jumlah penduduk sebanyak 261.890.900 jiwa menurut data Badan Pusat Statistik (BPS) tahun 2018. Di satu sisi, hal ini dapat menjadi keunggulan bersaing Indonesia karena surplus demografi yang dimiliki. Hal tersebut dapat terwujud jika Sumber Daya Manusia (SDM) tersebut dikelola dan dikembangkan dengan baik. Kemudahan akses pendidikan dan ketersediaan lapangan kerja merupakan kunci untuk mewujudkan SDM unggul tersebut, agar mampu bersaing dan mengejar ketertinggalannya dari negara lain. 
Sebaliknya, surplus demografi tersebut hanya akan menjadi bumerang bagi Indonesia jika pendidikan tidak dapat diakses secara merata dan lapangan pekerjaan tidak mampu menampung mereka. Maka semakin banyaklah tenagatenaga kerja tidak berpendidikan dan tidak terampil yang tidak terserap pasar tenaga kerja. Hal inilah yang sering mendorong Tenaga Kerja Indonesia untuk mencoba peruntungannya dan mengadu nasib bekerja di luar negeri. Di satu sisi, migrasi tenaga kerja ke luar negeri menjadi salah satu solusi pemecahan masalah pengangguran dan demografi. Namun disisi lain, jika kegiatan ini tidak dikelola dengan baik, maka masalah yang berkaitan dengan tenaga kerja di luar negeri justru akan menimbulkan masalah sosial yang baru

Undang-Undang No 39 Tahun 2004 Tentang Penempatan dan Perlindungan Tenaga Kerja Indonesia di Luar Negeri Pasal 1 ayat (1) mendefinisikan TKI sebagai Warga Negara Indonesia yang memenuhi persyaratan untuk bekerja di luar negeri dalam ikatan kerja untuk jangka waktu tertentu. TKI tersebut juga menerima upah sebagai imbalan atas kinerjanya. Selanjutnya, ayat (3) Undang-undang tersebut menjelaskan bahwa penempatan TKI merupakan proses mempertemukan TKI sesuai bakat, minat, dan kemampuannya dengan pemberi kerja di luar negeri. Proses penempatan tersebut meliputi rekrutmen, pengurusan dokumen, pelatihan, persiapan keberangkatan, keberangkatan ke negara tujuan, dan pemulangan ke negara asal.

Berdasarkan UU tersebut, penempatan TKI di luar negeri harus dilakukan oleh pemerintah atau lembaga penempatan TKI yang ditunjuk oleh penerintah. Dengan kata lain, penempatan TKI di luar negeri tidak dapat dilakukan oleh perseorangan. Namun pada praktiknya, masih banyak oknum perseorangan atau agen tidak resmi yang mengiming-imingi masyarakat dengan pekerjaan di luar negeri yang bergaji besar. Hal tersebut bertentangan dengan UU No.39/ 2004.
Sehubungan dengan penempatan TKI, saat ini pemerintah Indonesia telah membuat perjanjian tertulis dengan pemerintah negara tujuan. diantaranya dengan Korea Selatan dan Jepang atau yang dikenal dengan istilah Government to Government (G2G). Melalui skema ini, terjalin kesepakatan antar pemerintah untuk menempatkan TKI di perusahaanperusahaan yang berlokasi di kedua negara tersebut. Di sisi lain, pemerintah juga telah memberikan Surat Izin Pelaksana Penempatan TKI (SIPPTKI) bagi pihak swasta yang akan melakukan penempatan TKI di luar negeri. Dengan demikian, sudah jelas bahwa proses penempatan TKI hanya bisa dilakukan oleh pemerintah dengan skema kerjasama $\mathrm{G} 2 \mathrm{G}$, atau melalui agen legal yang telah mendapat izin pemerintah untuk melakukan penempatan.

TKI yang melaksanakan seluruh prosedur, aturan, dan mekanisme hukum tertulis dalam mendapatkan izin bekerja di luar negeri dinyatakan sebagai TKI legal. Mereka dibekali surat-surat resmi dan keberangkatan mereka tercatat di pangkalan data instansi pemerintah yang terkait ketenagakerjaan. Tidak hanya itu, mereka juga akan mendapat perlindungan hukum dari pemerintah Indonesia maupun pemerintah negara penempatan. Sehingga, apabila terjadi hal-hal yang berkaitan dengan hukum, pemerintah akan berusaha melindungi kepentingan dan hak-hak mereka. Lebih lanjut, mereka juga akan menandatangi surat perjanjian kerja antara TKI dan pihak yang mempekerjakan mereka di luar negeri. Kontrak tersebut mengatur lamanya masa kerja, hak dan kewajiban masing-masing pihak, dan hal lain yang diatur dalam perjanjian kerja tersebut. Cara inilah yang seharusnya ditempuh oleh setiap TKI yang hendak bekerja di luar negeri untuk menghindari hal-hal yang tidak diinginkan terjadi pada TKI.

Sayangnya, masih banyak juga dari mereka yang berangkat ke luar negeri secara illegal. Hal ini terjadi umumnya karena minimnya informasi dan 
pengetahuan masyarakat mengenai prosedur kerja yang legal. Mereka berangkat ke luar negeri tanpa izin resmi dari pemerintah. Bahkan, banyak pula diantara mereka yang memasuki negara lain tanpa dokumen yang sah. Hal ini menimbulkan risiko yang sangat fatal bagi kelangsungan hidup mereka di luar negeri. Beberapa pelanggaran yang sering mereka lakukan diantaranya yaitu bekerja di luar masa resmi tinggal, bekerja di sektor terlarang, bekerja tanpa surat perjanjian yang jelas. Mereka yang berangkat secara illegal tersebut tidak akan mendapatkan perlindungan hukum dari pemerintah karena mereka tidak terdaftar di pangkalan data pemerintah dan tidak memperoleh izin bekerja. Akibatnya, pemerintah tidak dapat ikut campur jika sesuatu hal terjadi pada TKI illegal di luar negeri. Laporan Badan Nasional Penempatan dan Perlindungan TKI (BNP2TKI) mengindikasikan adanya kenaikan jumlah TKI bermasalah dari tahun ke tahun (BNP2TKI, 2019).

Maraknya TKI bermasalah ini muncul sejak awal proses keberangkatan mereka dari Indonesia. Banyak TKI yang belum pernah ke luar negeri sebelumnya. Sehingga mereka tidak memahami dokumen-dokumen resmi ke luar negeri yang wajib mereka lengkapi seperti paspor, visa, maupun izin bekerja. Ketidaktahuan mereka ini akhirnya dimanfaatkan oleh oknum atau makelar yang datang ke desanya. Mereka menjanjikan kemudahan proses pengurusan dokumen, kepastian mendapatkan pekerjaan di luar negeri, bahkan mengiming-imingi gaji yang tinggi. Dengan pendidikan yang rendah dan terbatasnya keterampilan yang dimiliki, pada akhirnya mereka hanya mampu bekerja di sektor informal atau bekerja sebagai asisten rumah tangga (ART). Dengan jam kerja yang tidak terbatas, gaji yang rendah, bahkan ditutupnya akses komunikasi mereka dengan pihak luar, membuat kondisi mereka rentan dengan kekerasan, pelecehan, bahkan berujung pada kematian.
Persoalan lain terkait TKI adalah minimnya keterampilan yang mereka miliki. Hal ini berdampak pada rendahnya kinerja mereka. Padahal, pemerintah telah menetapkan persyaratan bagi para calon TKI untuk menempuh pelatihan selama 200 jam sebelum ditempatkan di luar negeri. Pelatihan tersebut akan membekali mereka dengan beberapa materi yang dapat menunjang kinerja mereka antara lain: bahasa negara tujuan, budaya negara tujuan, perlindungan hukum, serta ketrampilan dan kompetensi kerja. Pelatihan tersebut dapat ditempuh melalui Lembaga Pendidikan dan Keterampilan (LPK) dan Lembaga Sertifikasi Profesi (LSP) yang akan melakukan uji kompetensi kerja. Karena pelatihan dan uji sertifikasi tersebut memakan waktu yang tidak sebentar dan membutuhkan usaha yang keras, banyak diantara calon TKI yang mengambil jalan pintas dengan membeli sertifikat palsu dari oknum yang tidak bertanggung jawab tanpa melalui proses pelatihan dan ujian yang seharusnya. Akibatnya, kinerja mereka dibawah standar kinerja yang telah ditetapkan perusahaan pemberi kerja walaupun mereka telah mengantongi sertifikat pelatihan dan dinyatakan lulus uji kompetensi. Sejatinya, pelatihan tersebut mengajarkan mereka untuk berinteraksi secara efektif dengan pekerja dari negara lain. Selain itu pelatihan sebelum keberangkatan juga bertujuan untuk membuat mereka lebih cepat menyesuaikan diri dengan pekerjaan dan lingkungan baru mereka (Waxin \& Pannacio, 2005). Jenis pelatihan prakeberangkatan dapat meliputi pengenalan bahasa, budaya, kondisi kehidupan, adat dan kekhasan lokal (Mondy \& Noe, 2005).

Selanjutnya,

BNP2TKI mengemukakan bahwa jumlah warga asal Jawa Barat (Jabar) yang menjadi TKI merupakan yang terbanyak dibanding daerah lainnya yaitu sebanyak 50.910 orang pada tahun 2018. TKI asal Jabar tersebut berasal dari beberapa wilayah antara lain Indramayu, Cirebon, Cianjur, Sukabumi, Subang, Karawang, dan Majalengka. 
Berdasarkan negara penempatan, mayoritas TKI asal Jabar bekerja di Taiwan, Malaysia, dan Saudi Arabia. Tabel 1 menunjukkan 5 (lima) negara tujuan TKI asal Jabar.

Tabel 1. Lima Negara Tujuan TKI Provinsi Jawa Barat (Januari-Juli 2019)

\begin{tabular}{|c|l|c|}
\hline No & Negara Penempatan & Jumlah TKI \\
\hline 1 & Taiwan & 8.797 \\
\hline 2 & Malaysia & 5.097 \\
\hline 3 & Hongkong & 3.962 \\
\hline 4 & Singapura & 3.194 \\
\hline 5 & Brunei Darussalam & 409 \\
\hline
\end{tabular}

Sumber: Puslitfo BNP2TKI

Permasalahan yang terjadi pada TKI sebagaimana telah diuraikan diatas perlu diminimalisir agar tidak menimbulkan dampak penyalahgunaan, penyelewangan, eksploitasi, dan biaya sosial yang lebih besar. Pemerintah memahami bahwa tidak mungkin melarang warga negaranya bekerja di luar negeri. Untuk itu pemerintah perlu mengambil kebijakan guna meminimalisir permasalahan pada TKI dan dapat memberikan perlindungan yang menyuluruh pada setiap TKI.

Sebagai akademisi, permasalah sosial yang terjadi pada TKI telah menggugah kepedulian kami untuk mengambil bagian dalam mengentaskan permasalahan tersebut. Untuk itulah, sebagai wujud Tri Dharma Perguruan Tinggi, kami melakukan kegiatan Pengabdian Kepada Masyarakat khususnya di wilayah Jawa Barat mengenai proses rekrutmen, seleksi, pelatihan, serta perlindungan hukum bagi calon Tenaga Kerja Indonesia legal.

\section{METODOLOGI PELAKSANAAN}

Kegiatan Pengabdian Kepada Masyarakat ini dilaksanakan pada Hari Selasa, 16 Juli 2019 di Gedung KPGU, Kecamatan Ujung Jaya, Kabupaten Sumedang. Kecamatan Ujung Jaya merupakan salah satu kecamatan yang cukup banyak mengirimkan warganya untuk menjadi Calon TKI. Kecamatan Ujung Jaya sendiri terdiri dari 9 Desa dan berada Kabupaten Sumedang yang berbatasan langsung dengan Kabupaten Majalengka dan Kabupaten Indramayu.

Kegiatan Sosialisasi Proses

Rekrutmen, Seleksi, Pelatihan, Serta Perlindungan Hukum bagi para calon TKI dihadiri oleh kurang lebih 100 peserta yang berasal dari semua unsur yang ada di Kecamatan Ujung Jaya seperti dari unsur akademisi, unsur adat, unsur pemerintah, dan tentunya para calon TKI dan purna TKI.

Kegiatan dilakukan dalam bentuk seminar dengan mengusung tema Sosialisasi Proses Rekrutmen, Seleksi, Pelatihan, dan Perlindungan Hukum Bagi Calon Tenaga Kerja Indonesia (TKI) Legal di asal Jawa Barat. Seminar tersebut dibagi menjadi dua sesi yang diisi oleh pembicara yang ahli dibidangnya. Untuk sesi pertama, pembicara membahas mengenai proses rekrutmen hingga proses perlindungan hukum bagi para TKI yang disampaikan oleh Kepala BP3TKI, Bapak Delta S.H., M.H. Berikutnya untuk sesi kedua yang diisi oleh Bapak Teguh, selaku Ketua Komunitas Keluarga Buruh Migran juga sebagai tokoh adat setempat berbicara tentang pengalaman dan hal apa saja yang harus dilakukan ketika mendapati suatu permasalahan hukum di luar negeri.

Beberapa hal yang disampaikan pada kegiatan tersebut meliputi persyaratan calon TKI, dokumen yang harus dilengkapi, dan tahapan prosedur rekrutmen TKI legal. Persyaratan untuk menjadi TKI antara lain:

a) Berusia sekurang kurangnya 18 tahun, kecuali bagi Calon TKI yang dipekerjakan pada pengguna perorangan/rumah tangga sekurangkurangnya berusia 21 tahun.

b) Sehat jasmani dan rohani.

c) Memiliki keterampilan.

d) Tidak dalam keadaan hamil (TKI perempuan) 
e) Calon TKI terdaftar di Dinas Tenaga Kerja setempat.

f) Memiliki dokumen lengkap.

Kelengkapan dokumen yang harus dipenuhi adalah sebagai berikut:

a) KTP, Ijazah, Akte lahir/Surat kenal lahir.

b) Surat keterangan status perkawinan (Menikah/Belum menikah).

c) Surat keterangan ijin suami/ istri, orang tua atau wali.

d) Memiliki kompetensi kerja.

e) Surat keterangan sehat berdasarkan hasil pemeriksaan kesehatan dan psikologi.

f) Paspor.

g) Visa Kerja.

h) Perjanjian Penempatan PMI.

i) Perjanjian Kerja (PK).

j) Surat Keterangan telah mengikuti Pembekalan Akhir Pemberangkatan (PAP)

k) Kartu Tenaga Kerja Luar Negeri Elektronik (E-KTKLN).

Gambar 1. memberikan informasi mengenai prosedur rekrutmen TKI dari mulai pendaftaran hingga penempatan mereka ke negara tujuan. Bagi calon TKI yang telah memenuhi persyaratan dan melengkapi dokumen, dapat melakukan pendaftaran ke BP3TKI secara online. Setelah dokumen diverifikasi, selanjutnya akan dilakukan tes kemampuan dan psikotes. Untuk peserta yang lulus tes, akan dilakukan tes kesehatan (medical checkup) dan wawancara. Setelah itu, calon TKI akan mendapatkan pelatihan Bahasa Asing selama 6 bulan di Indonesia. Tes kesehatan kedua akan dilakukan setelah pelatihan. Apabila calon TKI telah melewati seluruh proses maka mereka akan diberi orientasi sebelum keberangkatan untuk kemudian diberangkatkan ke negara tujuan.

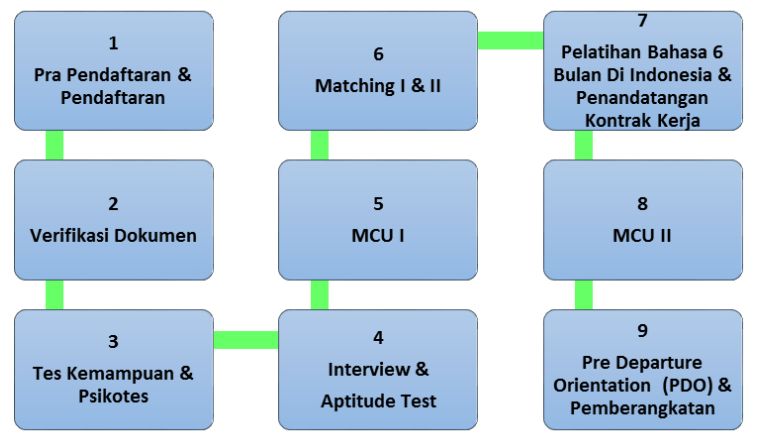

Gambar 1. Alur Rekrutmen dan Penempatan TKI

Sumber: BP3TKI Bandung, 2019

\section{HASIL DAN LUARAN}

Foto-foto Kegiatan

Berikut dokumentasi kegiatan:

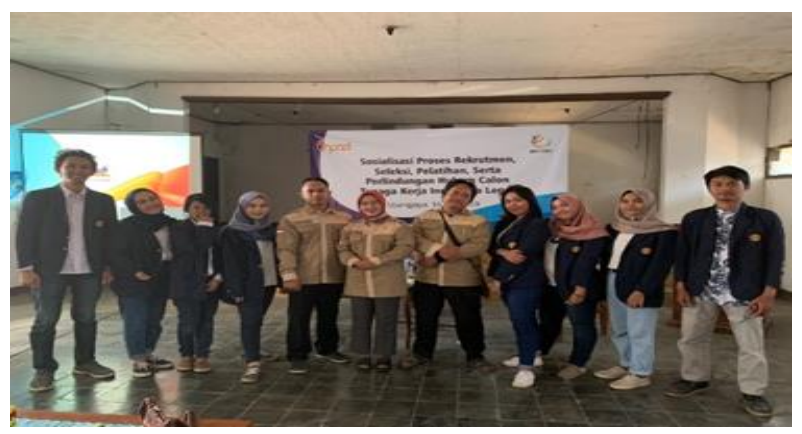

Gambar 2. Tokoh Masyarakat Ujung Jaya Bersama Mahasiswa PKM Universitas Padjadjaran

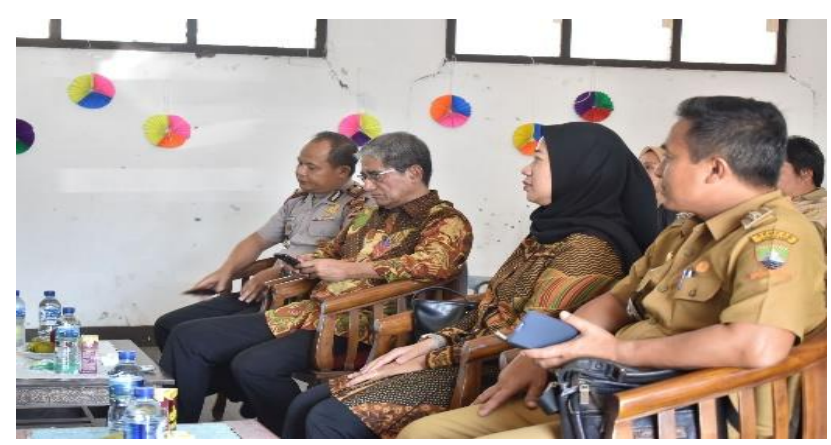

Gambar 3. Kapolsek Ujung Jaya, Kepala BP3TKI Bandung, Dosen FEB Unpad, dan Camat Ujung Jaya saat Menghadiri

Kegiatan 


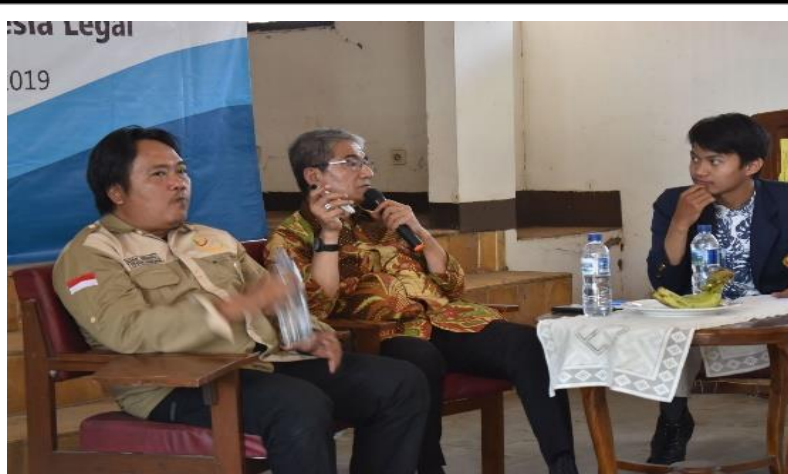

Gambar 4. Penyampaian Materi Oleh

Pembicara

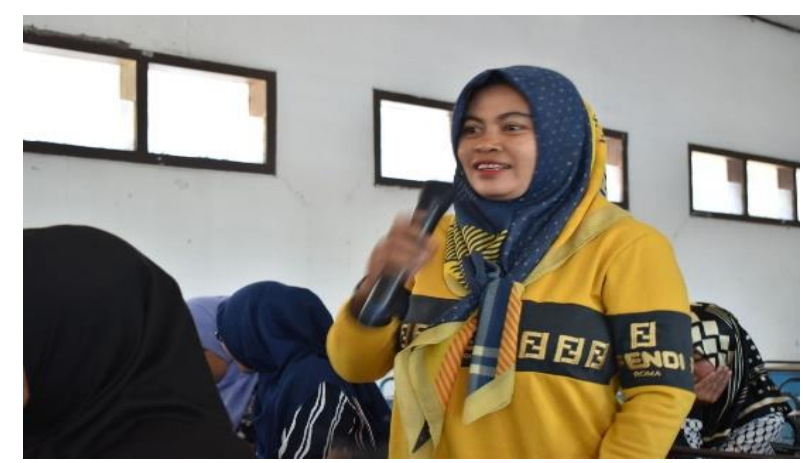

Gambar 5. Sesi Tanya Jawab Dengan Peserta

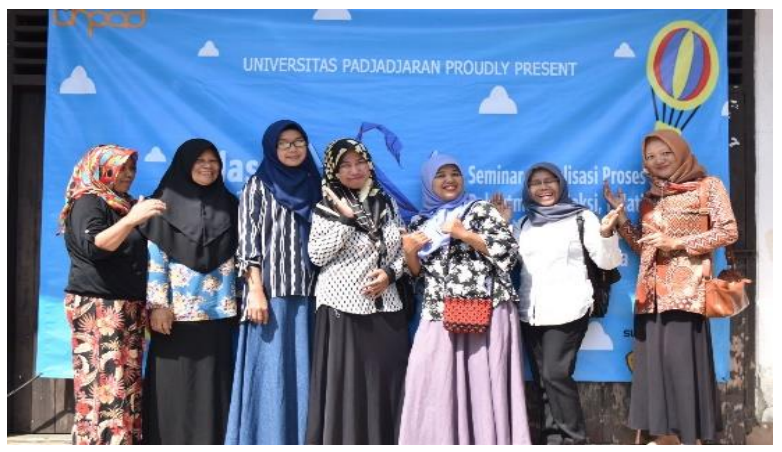

Gambar 6. Sebagian kecil Peserta yang Hadir

\section{Manfaat Kegiatan}

Manfaat kegiatan ini tidak hanya dirasakan bagi masyarakat Desa Ujung Jaya saja, tetapi bagi seluruh aparat desa dan pemerintah. Secara umum, manfaat yang diperoleh dari proses sosialisasi ini antara lain:
a) Masyarakat mengetahui Proses
Rekrutmen, Seleksi, Pelatihan, Serta Perlindungan Hukum Bagi TKI

sehingga mereka dapat menghindarkan diri dari agen-agen TKI yang illegal.

b) Masyarakat mengetahui hak serta kewajiban mereka jika mereka menjadi TKI.

c) Masyarakat memahami perlindungan hukum bagi TKI, sehingga mereka paham apa yang harus dilakukan jika terjadi hal-hal yang berkaitan dengan hukum saat di dalam maupun di luar negeri.

d) Aparat desa dan pemerintah dapat menghindari dan meminimalisir permasalahan sosial warganya yang terkait dengan TKI karena calon akan menempuh alur proses rekrutmen, seleksi, serta pelatihan yang legal saat mereka bekerja di luar negeri. .

Hasil dan Luaran

\begin{tabular}{|c|c|c|c|}
\hline $\begin{array}{l}\mathrm{N} \\
\mathrm{O}\end{array}$ & Hasil & Luaran & $\begin{array}{l}\text { Indikator } \\
\text { Capaian }\end{array}$ \\
\hline 1 & $\begin{array}{l}\text { Menguran } \\
\text { gi jumlah } \\
\text { TKI } \\
\text { illegal } \\
\text { asal Jawa } \\
\text { Barat }\end{array}$ & $\begin{array}{l}\text { Pengetah } \\
\text { uan } \\
\text { peserta } \\
\text { mengena } \\
\text { i agen- } \\
\text { agen } \\
\text { penyalur } \\
\text { TKI } \\
\text { yang } \\
\text { legal dan } \\
\text { illegal. }\end{array}$ & $\begin{array}{l}\text { Peserta hanya } \\
\text { mempertimba } \\
\text { ngkan agen- } \\
\text { agen penyalur } \\
\text { TKI legal saat } \\
\text { mendaftar } \\
\text { sebagai calon } \\
\text { TKI. }\end{array}$ \\
\hline 2 & $\begin{array}{l}\text { Meningka } \\
\text { tkan } \\
\text { pengetahu } \\
\text { an calon } \\
\text { TKI } \\
\text { mengenai } \\
\text { prosedur } \\
\text { rekrutmen } \\
\text {, seleksi, } \\
\text { dan } \\
\text { penempat } \\
\text { an TKI di } \\
\text { luar }\end{array}$ & $\begin{array}{l}\text { Peserta } \\
\text { mengeta } \\
\text { hui hak } \\
\text { dan } \\
\text { kewajiba } \\
\text { n yang } \\
\text { harus } \\
\text { dilakuka } \\
\text { n saat } \\
\text { menjadi } \\
\text { TKI. }\end{array}$ & $\begin{array}{l}\text { Peserta } \\
\text { memahami } \\
\text { dan } \\
\text { melaksanakan } \\
\text { hak dan } \\
\text { kewajibannya } \\
\text { saat akan dan } \\
\text { saat menjadi } \\
\text { TKI. }\end{array}$ \\
\hline
\end{tabular}




\begin{tabular}{|l|l|l|l|}
\hline & negeri. & & \\
\hline 3 & Meningka & Peserta & Peserta yang \\
& tkan & memaha & akan \\
& kompeten & mi & berangkat \\
& si TKI & bahwa & menjadi TKI \\
& melalui & mereka & mengikuti \\
& program & diwajibk & program \\
pelatihan. & an & pelatihan yang \\
& mengikut & diselenggarak \\
& i oleh \\
& & program & pemerintah \\
& pelatihan & maupun balai \\
& sebelum & latihan. \\
& ditempat & \\
& kan di & \\
& luar & \\
& negeri. & \\
& &
\end{tabular}

\section{KESIMPULAN}

Pelaksanaan sosialisasi di Kecamatan Ujung Jaya sudah dilaksanakan dengan baik dengan program yang yang sesuai dengan rencana. Diharapkan kegiatan ini menjadi langkah awal bagi masyarakat Desa Ujung Jaya dan para calon TKI khususnya, untuk dapat mengaplikasikan seluruh pengetahuan yang didapatkan selama sosialisasi. Edukasi terhadap calon TKI sebaiknya dilakukan sedini mungkin untuk menghindari permasalahan sosial di kemudian hari. Dengan demikian, jumlah TKI illegal serta risiko permasalahnnya di luar negeri dapat dikurangi.

\section{DAFTAR PUSTAKA}

BNP2TKI. (2018). Data penempatan dan perlindungan TMI tahun 2018. Jakarta: Badan Nasional Penempatan dan Perlindungan Tenaga Kerja Indonesia (BNP2TKI).

BNP2TKI. (2019). Data penempatan dan perlindungan TMI tahun 2019. Jakarta: Badan Nasional Penempatan dan Perlindungan Tenaga Kerja Indonesia (BNP2TKI).

Mondy, R.W., \& Noe, R.M. (2005). Human resource management ( $9^{\text {th }}$ ed.). USA: Pearson Education.

Undang-Undang Nomor $39 . \quad$ (2004). Penempatan dan Perlindungan Tenaga Kerja Indonesia di Luar Negeri.

Waxin, M., \& Pannacio, A. (2005). Crosscultural training to facilitate expatriate adjustment: it works! Personnel Review. 